\title{
Gujin Dan is a Chinese medicine formulation that stimulates cell proliferation and differentiation by controlling multiple genes involved in MC3T3-E1 cells
}

\section{Yu Zhou}

Changchun University of Chinese Medicine https://orcid.org/0000-0002-3065-4625

Chaozong Liu

University College London https://orcid.org/0000-0002-9854-4043

\section{Zhenwei Zhou}

Changchun University of Chinese Medicine https://orcid.org/0000-0003-3989-3435

Xin Li

Changchun University of Chinese Medicine https://orcid.org/0000-0003-0553-0767

\section{Songchuan Su}

Chongqing Orthopedic Hospital of Traditional Chinese Medicine https://orcid.org/0000-0002-23493165

\section{Liqi $\mathrm{Ng}$}

University College London https://orcid.org/0000-0002-7049-0012

\section{Jinghong Zhong}

Changchun University of Chinese Medicine https://orcid.org/0000-0003-2473-903X

\section{Ting-ting Wang}

Changchun University of Chinese Medicine https://orcid.org/0000-0002-3385-9036

\section{Wenlong Su}

Changchun University of Chinese Medicine https://orcid.org/0000-0002-2477-8859

Jie Yang

Changchun University of Chinese Medicine https://orcid.org/0000-0001-7322-3166

\section{Zeyu Peng}

Changchun University of Chinese Medicine https://orcid.org/0000-0003-4336-1335

\section{Shanyong Zhang (D23733198@qq.com)}

The Second Affiliated Hospital of Jilin University https://orcid.org/0000-0002-8576-9999

\section{Baojin Yao}

Changchun University of Chinese Medicine https://orcid.org/0000-0002-7542-1585

\section{Research Article}


Keywords: Gujin Dan extract, MC3T3-E1 cells, Differentially expressed genes, Molecular regulation, RNA sequencing

Posted Date: July 29th, 2022

DOI: https://doi.org/10.21203/rs.3.rs-1089993/v2

License: (c) (1) This work is licensed under a Creative Commons Attribution 4.0 International License. Read Full License 


\section{Abstract}

Background: With the development of Traditional Chinese medicine (TCM) in recent years, the use of TCM in the treatment of osteoporosis has received much attention and research. Gujin Dan (GJD) is one of the representative Chinese medicine formulations that work synergistically with 19 herbs and has been used for decades to treat cervical spondylosis, lumbar disc herniation, osteoarthritis and osteoporosis. However, the exact molecular mechanism by which GJD is used to strengthen bones in the treatment of osteoporosis remains largely unknown.

Methods: In this study, an aqueous extract of GJD was prepared and its components were identified by high-performance liquid chromatography (HPLC). The effect of GJD aqueous extract on MC3T3-E1 cells was determined by Cell Counting Kit-8 (CCK-8) assay, alkaline phosphatase (ALP), and alizarin red S staining (ARS), combined with RNA sequencing (RNA-seq) and qRT-PCR.

Results: Our study showed that GJD significantly promoted the proliferation of MC3T3-E1 cells, as well as the synthesis and mineralisation of the extracellular matrix. GJD significantly increased the expression levels of genes that promote cell proliferation such as Adamts1, Mcam, Cyr61, Fos, Cebpd, Fosl2, Sirt1, Nipbl, Sema3c and Kcnq1ot1, up-regulated genes that inhibit apoptosis such as Gadd45a, Birc3, upregulated genes that inhibit osteoclastogenesis such as Bcl6, Nfkbiz, Clcf1, Bcl3, Lgals3, Wisp1, Dusp1 and Fblim1, up-regulated genes that promote MC3T3-E1 cell differentiation such as Junb, Egr1, KIf10, Atf6, Malat1, Btg2, Sertad4, Zfyve16, Tet2, Creb5, Snai2, Fam46a, Calcrl and Pdzrn3. In addition, GJD mildly upregulated the expression levels of gene markers such as Atf4, Fn1, Usp7, Sox4, Col16a1, Spp1, Bmp1, Runx2, Bglap, Col12a1, and Alpl in osteoblasts.

Conclusions: Our results show that GJD promotes the differentiation and proliferation of MC3T3-E1 cells, inhibits osteoclast formation, and prevents osteoblast apoptosis. The present study significantly improves the current understanding of the molecular effects of GJD on MC3T3-E1 cells. This study also provides a new strategy for the further use of Chinese medicinal preparations against bone metabolismrelated diseases.

\section{Introduction}

Osteoporosis (OP) is the most common disease of bone metabolism and is rooted as an imbalance in bone remodelling, where bone resorption is greater than bone formation. With the ageing population, the prevalence of osteoporosis and the incidence of fragility fractures in China has increased significantly over the past 30 years[1,2], with studies showing that bone loss $(-2.5<\mathrm{T}$-score $<-1.0 \mathrm{SD})$ is as high as $44 \%$ and osteoporosis (T-score $\leq-2.5 \mathrm{SD}$ ) is as high as $37 \%$ in northeast China[3]. Although many drugs and modalities are currently available for the treatment of OP and have achieved some success, the increased side effects caused by long-term medication can also greatly reduce patient compliance [4-6]. Chinese medicine has a low-cost effect with fewer side effects, such as Xian-ling-gu-bao, which has also been used to treat osteoporosis with good results [7]. 
MC3T3-E1 is an osteoblast precursor cell line derived from the mouse parietal region, a useful model for osteoblast development-related experiments, representing immature osteoblasts. It has been shown that MC3T3-E1 is a continuous source of osteoblast regeneration that avoids the need for repeated preparation of primary osteoblasts and has a better balance and homogeneity than primary osteoblasts $[8,9]$.

Gujin Dan (GJD), developed by Professor Liu Bailing, is one of the typical Chinese medicine, which consists of 19 herbs acting synergistically, and has been used for decades in the treatment of cervical spondylosis, lumbar disc herniation, osteoarthritis and osteoporosis in the Department of Orthopaedics and Traumatology of Jilin Province Hospital of Traditional Chinese Medicin, China [10-12]. Clinically, the formulation is usually in the form of an oral pill for the treatment of patients with osteoporosis. Although its effect is effective and available in our hospital for the treatment of osteoporotic diseases, the exact molecular mechanism of its efficacy in the treatment of osteoporosis remains to be elucidated.

In this experiment, GJD aqueous extract was prepared, and the main components of the aqueous extract were detected by high-performance liquid chromatography (HPLC). The effect of GJD on the differentiation and proliferation of MC3T3-E1 cells was investigated and confirmed. Transcriptome analysis was performed by RNA sequence analysis of MC3T3-E1 cells in response to GJD treatment, and differentially expressed genes were screened by bioinformatics analysis. These results provide ideas to unravel the effects of GJD on osteoblasts and osteoblast-associated bone diseases.

\section{Materials And Methods}

\subsection{Preparation of GJD aqueous extracts}

GJD was obtained from the Affiliated Hospital of Changchun University of Chinese Medicine (Changchun, China). The formulation of GJD is composed of 19 Chinese materia medica (CMM), namely Drynariae Rhizoma, Spatholobi Caulis, Epimedium, Radix Rehmanniae Praeparata, Paederia Scandens, Cynanchum paniculatum, Curcuma longa, Achyranthes Bidentata, Pericarpium Citri Reticulatae, Radix Paeoniae Alba, Cornu Cervi Degelatinatum, Liquorice, Eucommia ulmoides, Testudinis Carapax et Plustrum, Corydalis yanhusuo, Eupolyphaga Sinensis Walker, Zaocys Dhumnade, Coicis Semen, Cornus Officinalis. The CMM mixture of GJD was extracted by reflux with distilled water and then passed through a $0.45-\mu \mathrm{m}$ hollow fibre cartridge (GE Healthcare, USA). The filtrate was freeze-dried in a Heto PowerDry LL3000 freeze-dryer (Thermo, USA) and stored at $-80^{\circ} \mathrm{C}$. Before using the drug in the experiment, $0.1 \mathrm{~g}$ of GJD freeze-dried powder was added directly to $10 \mathrm{ml}$ of culture medium and vortexed to dissolve, and left to stand for $15 \mathrm{~min}$. After the drug and medium were completely dissolved, the dissolved mixture was filtered through a $0.22-\mu \mathrm{m}$ hollow fibre cartridge (GE Healthcare, USA) and added to the cells.

2.2 HPLC analysis of GJD aqueous extract 
The chemical profile of GJD aqueous extract was determined by high-performance lipid chromatography (HPLC). Standard chemicals (Paeoniflorin, Pinoresinol diglucoside, Loganin, Liquiritin, Acteoside,

Tetrahydropalmatine, Naringin, Icariin, Ammonium glycyrrhetate and Catalpol) were purchased from National Institute for Food and Drug Control (Beijing, China). HPLC analysis of GJD extracts was carried out using a liquid chromatography system ZORBAX SB $(250 \mathrm{~mm} \times 4.6 \mathrm{~mm}, 5 \mu \mathrm{m})$ (Agilent, USA). The mobile phase was a gradient elution system consisting of acetonitrile (A) - $0.1 \%$ phosphoric acid water (B) at a flow rate of $1 \mathrm{ml} / \mathrm{min}$ as follows: 0-8 $\mathrm{min}, 7 \%-15 \% \mathrm{~A}, 8-25 \mathrm{~min}, 15 \%-20 \% \mathrm{~A}, 25-45 \mathrm{~min}, 20 \%-35 \% \mathrm{~A}$, 45-60 min, 35\%-45\%A, 60-80 min, 45\%-55\%A, 80-110 min, 55\%A, 80 110 min, 55\% 60\%A, 110 120 min, $60 \% \sim 70 \%$ A, 120 140 min, 70\% 80\%A. A photodiode array (PDA) detector was set at $254 \mathrm{~nm}$.

2.3 Culture of MC3T3-E1 osteoblast-like cells and induction of osteoblast differentiation

MC3T3-E1 cells were cultured in DMEM (Hyclone, China) containing 10\% fetal bovine serum (FBS, Gibco), $100 \mathrm{U} / \mathrm{mL}$ penicillin, and $100 \mathrm{mg} / \mathrm{mL}$ streptomycin at $37^{\circ} \mathrm{C}$ in $5 \% \mathrm{CO}_{2}$. MC3T3-E1 cells were inoculated into 24-well cell culture plates at a density of $3 \times 10^{4}$ cells/well, and replace with fresh medium every 2-3 days. When the cells reached $80 \%$ fusion, the cell culture medium was discarded and add the osteogenic differentiation medium (DMEM supplemented with 10\% FBS, $50 \mu \mathrm{g} / \mathrm{mL}$ Ascorbic acid, $10 \mathrm{mM} \beta$ Glycerophosphate) was treated with the optimal concentration of GJD for 7 days, replace osteogenic differentiation medium every 2-3 days, and these cells were then used for further studies.

\subsection{Cell proliferation assay}

MC3T3-E1 cell viability was assessed using the Cell Counting Kit-8 (CCK-8) (Sigma, USA) according to the manufacturer's protocol. Briefly, MC3T3-E1 cells (ATCC, USA) were inoculated at a density of $3 \times 10^{4}$ cells/well into 96-well cell culture plates (Thermo, USA) $(100 \mu \mathrm{l})$ and incubated in a humidified incubator (Thermo, USA) containing $5 \% \mathrm{CO}_{2}$ at $37^{\circ} \mathrm{C}$ for 24 hours. The cell culture medium was then discarded and MC3T3-E1 cells were treated with different concentrations of GJD $(0,0.1,0.2,0.4,0.8,1.6,3.2$, and $6.4 \mathrm{mg} / \mathrm{ml}$ dissolved in the medium; $100 \mu \mathrm{l}$ per well) and subsequently incubated for $24 \mathrm{hr}$. Followed by the addition of $10 \mathrm{ul}$ of CCK-8 reagent and the cells were incubated for $1 \mathrm{~h}$. Absorbance was measured at $450 \mathrm{~nm}$ using an Infinite 200 PRO ELISA (Life Sciences, USA). Cell proliferation rate was calculated as the percentage of cell viability after treatment with different concentrations of GJD, respectively.

2.5 Alkaline Phosphatase Staining and Activity Measurement

MC3T3-E1 cells were inoculated into 24-well cell culture plates at a density of $3 \times 10^{4}$ cells/well, and replace with fresh medium every $2-3$ days. When the cells reached $80 \%$ fusion, the cell culture medium 
was discarded and add the osteogenic differentiation medium was treated with the optimal concentration of GJD for 7 days, and replace osteogenic differentiation medium every 2-3 days. After discarding the cell culture medium and rinsing the residue with PBS, the cells were fixed in $4 \%$ paraformaldehyde at $4^{\circ} \mathrm{C}$ for 30 minutes, then rinsed again with PBS and stained with the BCIP/NBT Alkaline Phosphatase (ALP) staining kit (Beyotime, China) according to the manufacturer's protocols by mixing $33 \mu$ of BCIP solution, $66 \mu \mathrm{l}$ of NBT solution and $10.1 \mathrm{ml}$ of BCIP/NBT working solution was mixed and added to the cells for 2 hours. Images were taken with a light microscope (Olympus, Japan) and a digital camera. MC3T3E1 cells were treated as described above and proteins were extracted to determine the enzymatic activity of alkaline phosphatase. The alkaline phosphatase assay kit (Beyotime, China) was used accordingly with the manufacturer's protocol to measure alkaline phosphatase activity. Infinite 200 PRO ELISA was used to measure the absorbance of alkaline phosphatase activity of $405 \mathrm{~nm}$.

\subsection{Alizarin Red S Staining and Calcium Assay}

MC3T3-E1 cells were inoculated into 24-well cell culture plates at a density of $3 \times 10^{4}$ cells/well, and replace with fresh medium every 2-3 days. When the cells reached $80 \%$ fusion, the cell culture medium was discarded and add the osteogenic differentiation medium was treated with the optimal concentration of GJD for 7 days, replacing the osteogenic differentiation medium every 2-3 days. After discarding the medium and rinsing the residue with PBS, the cells were fixed in a fixative solution using the Osteoblast Mineralisation Nodule Staining Kit (Beyotime, China) according to the manufacturer's instructions for 30 minutes, rinsed three times with PBS, and stained with an appropriate amount of Alizarin Red S staining solution for 30 minutes at room temperature. Images were taken with a light microscope (Olympus, Japan) and a digital camera and quantified using a plate reader (Life science, USA) at an optical density (OD) of $405 \mathrm{~nm}$ [13].

\subsection{RNA purification and Illumina sequencing}

MC3T3-E1 cells were inoculated into 6-well cell culture plates at a density of $10 \times 10^{5}$ cells/well and incubated for $24 \mathrm{~h}$. MC3T3-E1 cells were treated with GJD for $24 \mathrm{~h}$ or left untreated. The cell culture medium was then discarded, and each well was thoroughly rinsed with cold PBS buffer. According to the Manufacturer's instruction, TRIzol (Invitrogen, USA) was used to isolate total RNA, and Agilent 2100 Bioanalyzer (Agilent Technologies, USA) was used to assess the RNA integrity. TruSeq Stranded mRNA kit (Illumina, USA) was used to generate double-end mRNA libraries following the manufacturer's protocol. high-throughput sequencing of mRNA libraries was performed on the Illumina HiSeq 2500 platform (Illumina, USA). 


\subsection{RNA-Seq data analysis}

After RNA-seq, clean reads are obtained by trimming the raw reads to remove low-quality reads and splice sequences. The dataset is stored in the NCBI Sequence Read Archive (SRA) database under accession number PRJNA780206. Clean reads were aligned to the mouse (Mus musculus) reference genome using HISAT [14]. Gene expression levels were measured using the Fpkm algorithm [15]. Non-redundant (NR) and Swiss-Prot protein databases were annotated with BLAST. DEGseq was used to analyse differentially expressed genes. Genes with a log 2 fold change $\geq 1$ or $\leq-1$ and with a $p$-value $\leq 0.001$ were considered to be differentially expressed. The False discovery rate冈FDR $₫$ was generated using the Benjamini and Hochberg methods[16].

\subsection{Quantitative real-time PCR (qRT-PCR) validation}

qRT-PCR was used to verify the expression levels of differentially expressed genes. Briefly, total RNA was isolated using TRIzol (Invitrogen, USA) according to the manufacturer's protocol. cDNA was synthesised using the iScript cDNA Synthesis Kit (Bio-Rad, USA) and standard amplification conditions were applied using the SsoAdvanced Universal SYBR $\circledast$ Green Supermix (Bio-Rad, USA) on the CFX Connect Real-Time PCR Detection System (Bio-Rad, USA) on the CFX Connect Real-Time PCR Detection System (Bio-Rad, USA) to amplify standard amplification conditions. Gene expression levels were normalised to the mouse glyceraldehyde 3-phosphate dehydrogenase (Gapdh) gene as an internal reference gene and calculated using the $2-\Delta \Delta C T$ method [17].

\section{Results}

\subsection{Chemical Quality Control of GJD}

The chemical quality control results for GJD are shown in Figure 1. The chemical compound compositions were the same as previously reported and included Paeoniflorin, Pinoresinol diglucoside, Loganin, Liquiritin, Acteoside, Tetrahydropalmatine, Naringin, Icariin, Ammonium glycyrrhetate and Catalpol.

3.2 GJD promotes the proliferation of MC3T3-E1 cells in a dose-dependent manner

The proliferation of MC3T3-E1 cells due to the effects of GJD treated 24 hours measured by CCK-8 assay as shown in Figure 2. Cell viability was significantly increased in a dose-dependent manner in the GJD treatment compared to the untreated control $(0 \mathrm{mg} / \mathrm{ml})$. The GJD concentration of $3.2 \mathrm{mg} / \mathrm{ml}$ was chosen for subsequent experiments as treatment with $3.2 \mathrm{mg} / \mathrm{ml}$ had a significant effect on cell viability. 


\subsection{Alkaline phosphatase and Alizarin Red S Results}

MC3T3-E1 cells cultured for 7 days after GJD treatment by osteogenic induction of differentiation were observed microscopically by ALP and ARS staining of cells compared to untreated cells. We observed that MC3T3-E1 cells after treatment by GJD could promote cell proliferation and differentiation.

Furthermore, the results of quantitative analysis of ARS and ALP in each group were consistent with the microphotographic results (Figure 3-4).

\subsection{Sequencing, genome mapping and functional annotation}

After Illumina sequencing and data processing, 44,599,448 and 47,323,148 clean reads were obtained for MC3T3-E1 cells not treated with GJD (blank) and MC3T3-E1 cells treated with GJD, respectively, as shown in Table 1. The quality assessment indicated that the Q30 percentage was greater than $95 \%$ and the GC content percentage was approximately $51 \%$. For the blank and GJD treated samples, $41,360,834$ and $44,185,514$ reads were compared to the mouse genome respectively. In total, 12,977 of 13,070 (blanks) and 13,282 of 13,383 (GJD) transcripts were annotated against the non-redundant (NR) NCBI Protein Data Bank and the Swiss-Prot database, respectively.

\subsection{Comparative analysis of differentially expressed genes}

The 362 genes that were identified via differential expression analysis were significantly differentially expressed between the GJD-treated and Blank groups (log 2-fold change $\geq 1$ or $\leq-1$ and $p \leq 0.001$ ), including 346 up-regulated genes and 16 down-regulated genes (GJD vs. blank), as shown in Table 2.

\subsection{Gene Ontology (GO) functional enrichment analysis of DEGs}

Based on the functional enrichment analysis of DEGs, the identified DEGs were classified into the following GO categories: biological processes, cellular components, and molecular functions, as shown in Figure 5. The classification of biological processes shows that DGEs mainly include the regulation of the cellular process, metabolic process, single-organism process, and biological regulation. The cellular component also shows that the majority of DGEs are located in the cell, cell part and organelle regions. For molecular function classification, the results show that DGEs are mainly associated with binding, catalytic activity, nucleic acid binding transcription factor activity and molecular function regulator.

3.7 GJD increases the expression levels of multiple genes that positively regulate the proliferation of MC3T3-E1 cells or osteoblasts 
As GJD promotes the proliferation of MC3T3-E1 cells, we first analysed differentially expressed genes that positively regulate the proliferation of MC3T3-E1 cells or osteoblasts. We identified 10 differentially expressed genes based on the results from RNA-seq analysis that directly promote cell proliferation, including Adamts1, Mcam, Cyr61, Fos, Cebpd, Fosl2, Sirt1, Nipbl, Sema3c and Kcnq1ot1. The expression levels of these genes were significantly increased in response to GJD treatment, as shown in Table 3.

3.8 GJD treatment increases the expression levels that inhibit osteoblast apoptosis to maintain cellular activity

We analysed differentially expressed genes involved in the inhibition of osteoblast apoptosis. Overall, the expression levels of the four genes were significantly altered in response to GJD treatment. These genes are normally altered when cells are in a proliferative state and play a key role in the inhibition of apoptosis, as shown in Table 4.

3.9 GJD treatment maintains cellular activity and proliferation by inhibiting osteoclast growth or differentiation

We went on to analyse differentially expressed genes involved in the inhibition of osteoclast growth and differentiation. In general, the significant upregulation of the expression levels of 10 genes was in response to GJD treatment. These genes are normally down-regulated when the cells are in a proliferative state and play a key role in inhibiting osteoclast proliferation, as shown in Table 5.

3.10 GJD increases the expression levels of several genes that promote differentiation of MC3T3-E1 cells and osteoblasts

Among the identified DEGs, we analysed differentially expressed genes involved in promoting cell differentiation. In response to the GJD treatment, the expression levels of 20 genes were significantly upregulated. These genes are normally up-regulated and Pdzrn3 is down-regulated when the cells are in a differentiated state. As shown in Table 6.

3.11 GJD mildly increases the expression level of osteoblast markers in MC3T3-E1 cells

In addition, the expression levels of osteoblast markers including Atf4, Fn1, Usp7, Sox4, Col16a1, Spp1, Bmp1, Runx2, Bglap, Col12a1 and Alpl were slightly increased after GJD treatment according to RNA-seq analysis, as shown in Table 7. 
To verify the accuracy of the RNA-seq results, eight differentially expressed genes (Adamts1, Mcan, Cebpd, Gadd45a, Bcl3, Nfkbiz, junB, Klf10 and Hspa1b) were selected and their expression profiles were verified using qRT-PCR. The specific primers used in this experiment are listed in Table 8.

Relative ploidy changes for each gene were normalized to the internal reference gene Gapdh. qRT-PCR measurements of the expression levels of selected differentially expressed genes were consistent with the results of RNA-seq analysis, as shown in Figure 6.

\section{Discussion}

GJD is a Chinese medicinal preparation widely used for the treatment of osteoporotic diseases and has been used for decades in Jilin Provincial Hospital of Traditional Chinese Medicine. However, the precise molecular mechanisms behind the ability of GJD to treat these diseases remain to be elucidated. In this study, we investigated the effects of GJD on MC3T3-E1 cells using state-of-the-art RNA-seq technology. From the results of the CCK-8 assay, in a dose-dependent manner, the proliferation of MC3T3E1 cells was significantly promoted by GJD. We then performed RNA-seq to further explore the mechanisms that are responsible for regulating cell proliferation in response to GJD treatment.

We first analysed the differentially expressed genes involved in increased cell proliferation. The significant increase in the expression levels of several genes involved in promoting cell proliferation via GJD include Adamts1, Mcam, Cyr61, Fos, Cebpd, Fosl2, Nipbl, Sema3c and Sirt1. Adamts1 is a secreted multifunctional metalloproteinase and an early responder to parathyroid hormone (PTH) in osteoblasts. Upregulation of Adamts1 promotes osteoblast growth and mineralisation and is an effective regulator of bone remodelling [18]. Mcam gene expression is in response to "metaphyseal mesenchymal progenitors" (MMPs), which play a key role in osteoblast proliferation and differentiation. MSCs express marker genes [19]. It is well known that bone morphogenetic proteins (BMPs), especially BMP-2, are key regulators of osteogenesis, and the literature demonstrates that CYR61 enhances BMP-2 mRNA and protein expression in a time- and dose-dependent manner to significantly increase proliferation and osteoblast differentiation in MC3T3-E1 cells and primary cultured osteoblasts, and is associated with multiple pathways, such as the ILK and ERK signalling pathway, and the canonical Wnt pathway [20]. Fos (also known as the c-fos gene) is part of the AP-I (activator protein 1) transcription factor, which can increase MC3T3-E1 cell proliferation through JNK, ERK and p38 MAPK signalling pathways [21]. Several studies have shown that Cebpd is associated with target genes for a variety of biological functions, including growth arrest, apoptosis, differentiation, stem cell self-renewal and tumour suppression, and that in osteoblasts and MC3T3-E1 cells, Cebpd upregulation promotes cell proliferation and differentiation and plays a key role in bone growth and bone remodelling [22]. The literature reports that SIRT1, a regulator of bone mass, is closely related to bone metabolism and bone mass and that SIRT1 overexpression promoted proliferation, differentiation and prevented autophagic apoptosis of МСЗТЗ- 
E1 cells and was able to inhibit osteoclast differentiation [23-25]. Kcnq1ot1 is associated with a variety of tumourigenesis, and upregulation of Kcnq1ot1 promotes MC3T3-E1 cell proliferation and osteoblast differentiation [26]. Our results show that GJD treatment significantly promotes osteoblast proliferation by upregulating the expression levels of functional genes involved in promoting cell proliferation.

In line with these results, we also found that the levels of several genes involved in the inhibition of osteoclast differentiation were significantly upregulated after GJD treatment, such as Bcl3, Bcl6, Nfkbiz, Sirt1, Clcf1, and Kcnq1 ot1. It has been shown that B-cell chronic lymphatic leukaemia protein 3 (Bcl3) interacts with tumour necrosis factor receptor-associated factor 6 through its anchor protein repeat domain to attenuate RANKL-induced osteoclast bone resorption activity and inhibit osteoclast growth in bone marrow-derived macrophages in vitro [27]. B cell lymphoma $6(\mathrm{Bcl} 6)$ is a negative regulator of osteoclastogenesis and overexpression of Bcl6 effectively inhibits osteoclast differentiation in vitro [28]. Nfkbiz is a key transcription factor involved in osteoclast differentiation, and upregulation of Nfkbiz can mediate impaired osteoclast differentiation [29]. Galectin-3 (encoded by the LGALS3 gene) is a member of the $\beta$-galactoside-binding lectin family that play multiple roles in cell growth, differentiation and aggregation, interfering with RANLK-mediated signalling and has an intrinsic inhibitory effect on osteoclastogenesis, and overexpression of Lgals3 promotes osteogenic differentiation [30,31]. Wisp1, a member of the CCN family that is found in mineralized tissues and is produced by osteoblasts and their precursors, down-regulation of Wisp1 promotes osteoclast differentiation, whereas up-regulation promotes osteoblast differentiation [32].

We further found that the expression levels of several genes involved in the inhibition of apoptosis were significantly altered after GJD treatment, such as Gadd45a, Birc3, Sirt1 and Hspa1b. Gadd45a is a target gene for the FoxO3a transcription factor, Gadd45a is also a DNA damage repair gene, and its upregulation eliminates pro-apoptotic genes in damaged or abnormal cells [33]. Birc3 is part of a family of apoptosis-inhibiting proteins that effectively mediates resistance to cell death [34]. Negative regulation of Hspa1b, an apoptosis-related factor, inhibits osteoblast apoptosis [35]. Our results show that GJD treatment inhibits apoptosis through significant changes in the expression levels of functional genes involved in the inhibition of apoptosis.

As well, we analysed that the expression levels of most genes involved in MC3T3-E1 cells and osteoblasts to promote their differentiation and mineralisation were significantly upregulated after GJD treatment, such as Lgals3, Adamts1, Junb, Egr1, Klf10, Atf6, Wisp1, Malat1, Btg2, Sirt1, Sertad4, Zfyve16, Creb5, Snai2, Fblim1, Fam46a, Calcrl, Kcnq1 ot1, Pdzrn3. Overexpression of the AP-1 transcription factor JunB induces osteoblast differentiation [36]. Egr1 co-regulates osteoblast differentiation with several osteoblast-related genes and Egr1 overexpression contributes to osteoblast differentiation [37,38]. Klf10 is a member of the Krüppel-like family of transcription factors, Klf10 upregulation effectively promotes osteoblast differentiation [39]. Osteocalcin is a target gene of ATF6, ATF6 upregulation promotes osteoblast differentiation [40]. Malat1 (metastasis-associated lung adenocarcinoma transcript 1) is associated with a variety of human tumours and Malat1 upregulation mediates the regulation of osteoblast activity and pro-differentiation [41]. Sertad4 is a newly identified gene associated with 
osteoporosis, and upregulation of Sertad4 promotes osteoblast differentiation [42]. The Zinc finger fyve domain containing 16 (ZFYVE16, also known as Endofin) is involved in the BMP signalling pathway playing an important role in promoting osteoblast differentiation [43]. Creb5 is relevant to the treatment of several cancer diseases, and studies of osteoblast differentiation have revealed that this Creb5 upregulation promotes osteoblast differentiation [44]. Snail2 is a marker of malignancy in epithelial tumours, and upregulation of Snail2 was shown to promote increased osteoblast alkaline phosphatase activity and promote differentiation [45]. Fblim1 is a key regulator of bone homeostasis and deletion of the Fblim 1 gene results in increased differentiation of osteoclasts in vivo [46]. FAM46A is a gene associated with skeletal dysplasia and bone mineralization and plays an important role in bone regulation, and FAM46A deficiency can lead to fracture susceptibility and long bone curvature [47]. CALCRL (Calcitonin receptor-like receptor) is associated with disease and CALCRL upregulation promotes osteoblast differentiation [48]. PDZRN3 is a member of the PDZ domain-containing RING finger family of proteins and plays an important role in the negative feedback control of osteoblast differentiation by inhibiting Wnt- $\beta$-catenin signalling [49].

Based on our RNA-seq, we also analysed the expression levels of osteoblast markers, including Atf4, Fn1, Usp7, Sox4, Col16a1, Spp1, Bmp1, Runx2, Bglap, Col12a1 and Alpl, which were slightly increased in response to GJD treatment. Based on our RNA-seq, we also analysed the expression levels of osteoblast markers, including Atf4, Fn1, Usp7, Sox4, Col16a1, Spp1, Bmp1, Runx2, Bglap, Col12a1 and Alpl, which were slightly increased in response to GJD treatment. Studies confirmed that SPP1, Fn1, Bglap, Col16a1, and Col12a1 are the main bone matrix proteins with associated genes [50-53]. ATF4, SOX4, RUNX2 are key transcription factors associated with bone formation [54-56]. It has been shown that ubiquitinspecific proteinase 7 (USP7) is involved in the regulation of various biological functions and plays an important role in osteoblast differentiation [57]. Bmp1 is a member of the bone morphogenetic protein family and plays an important role in bone remodelling [58]. Alpl is a marker of osteoblasts and is mostly used in the important assessment of bone formation [59].

There are also genes in the RNA-Seq that are significantly upregulated or downregulated by drug interventions, which we have not included in the analysis because they are not relevant to our topic, so we have only analysed genes associated with osteoporosis disease. Other data may also be useful for subsequent studies of other diseases.

The GJD is based on the clinical experience of Professor Bailing Liu, a master of Chinese medicine, and is designed under the guidance of the basic theory of Chinese medicine, with the theory that "the kidney is the master of bone" and "treating the kidney also treats the bone". Among the nineteen CMMs in GJD, Bonesetter, Epimedium, Radix Rehmanniae Praeparata, Achyranthes bidentata, Eucommia ulmoides and Cornus officinalis are the drugs that play the most important role in Chinese medicine formulation, the so-called monarchs and ministers, all these herbs are drugs that play a role in Chinese medicine in tonifying the kidneys and strengthening the bones. The so-called kidney is not simply limited to one organ but is a function of the Zang viscera system under the general theory of Chinese medicine. The Qi in the Zang viscera kidney is Kidney Qi, which promotes and regulates the growth and 
development of the bones [60,61]. Rhizoma Dynariae is one of the medicines in the Chinese Pharmacopoeia, mainly used for the treatment of bone-related diseases. Its main component is Flavonoids, which have been proven in numerous studies to have the effect of reducing bone loss and promoting bone formation [62]. Epimedium has been shown to promote osteogenic differentiation and thus induce bone formation [63]. Radix Rehmanniae Praeparata is one of the most commonly used herbs in Chinese medicine and has been shown in numerous experimental studies to have therapeutic effects on diseases such as osteoporosis through its many active ingredients [64]. Achyranthes bidentata is used in many prescriptions in Chinese medicine, which shows its wide range of effects, and studies have shown that this herb has significant anti-osteoporosis effects [65]. Eucommia ulmoides is a common herbal medicine used in Chinese medicine for the treatment of osteoporosis, which has the effect of regulating bone metabolism and is mostly used for the prevention and treatment of osteoporosis [66]. Studies of Cornus Officinalis extract were found to inhibit osteoclast differentiation and promote osteoblast differentiation [67]. In addition, studies have shown that the Curcuminoid-enriched Turmeric extract in Curcuma Longa helps retain BMD in trend-model rats, as well as the microarchitectural structure and Trabecular connectivity of bone [68]. Pericarpium Citri Reticulatae contains Hesperetin, according to the research, Hesperetin effectively suppressed Rankl-induced osteoclastogenesis, osteoclastic bone resorption and F-actin ring [69]. Radix Paeoniae Alba containing Paeoniflorin has been widely used in the treatment of osteoporosis. Paeoniflorin treatment of osteoporosis can be divided into two general directions: inhibiting osteoclast activity [70] and improving osteoblast activity [71,72], It slows bone resorption by inhibiting osteoclast activity and promotes bone formation by increasing osteoblast

activity. Corydalis Yanhusuo contains Tetrahydropalmatine, Experimental studies in vivo and in vitro have shown that Tetrahydropalmatine inhibits osteoclast formation by inhibiting NF-KB and MAPK pathways [73]. Coicis Semen extract has been shown to promote osteoblast proliferation and effectively relieve osteoporosis in animals [73-75].

In conclusion, our results suggest that the various herbs and their active ingredients in GJD synergistically promote osteoblast proliferation and differentiation and also inhibit osteoclast differentiation and inflammation.

\section{Conclusion}

This study shows that GJD, a Chinese medicine formulation that has been used for decades to treat osteoporosis and other bone metabolic diseases, significantly promoted the viability and proliferation of MC3T3-E1 cells, kept the cells in a sustained proliferative state, promoted their differentiation and inhibited osteoclastogenesis and differentiation. These effects were achieved through the synergistic interaction of the active ingredients of the various herbs in GJD, in which increased functional gene expression levels involved in osteoblast proliferation and differentiation and decreased the expression levels of genes involved in osteoclastogenesis and differentiation. Treatment with GJD also reduced the expression levels of genes involved in cellular pro-apoptosis. Thus, this study significantly deepens the current understanding of the molecular effects of GJD on MC3T3-E1 cells. This study would also provide 
new ideas with the use of traditional Chinese medicinal preparations in further preventing and treating bone metabolism-related diseases.

\section{Declarations}

Author's contribution

ZY, SY and BJ designed the paper, ZW, LX, JH, TT and WL completed the experiment, ZY and JY collected and sorted out the data, ZY drafted the manuscript, CZ, SC, LQ, SY and BJ edited the manuscript. All authors have read and approved the manuscript.

Competing interests

No conflict of interest exists in the submission of this manuscript. I would like to declare on behalf of my co-authors that the work described is original research that has not been published previously, and is not under consideration for publication elsewhere, in whole or in part. All the authors listed have approved the manuscript that is enclosed.

Acknowledgement:

The authors would like to thank the financial support from the Engineering and Physical Science Research Council (EPSRC) via the DTP CASE programme (Grant No: EP/ T517793/1), Innovation Team and Talents Cultivation Program of National Administration of Traditional Chinese Medicine (No: ZYYCXTD-D-202001) and the TCM Clinical Research Center for Bone diseases of Jilin Province (Grant No: $20180623048 \mathrm{TC}$ ). The funding source had the role in design, execution and the decision to submit the manuscript for publication.

Associated Data

Data Availability Statement

The data sets were deposited in the NCBI Sequence Read Archive (SRA) database under accession number PRJNA780206.

\section{References}

1. Cheng X, Zhao K, Zha X, et al. Opportunistic Screening Using Low-Dose CT and the Prevalence of Osteoporosis in China: A Nationwide, Multicenter Study. J Bone Miner Res. 2021;36(3):427-435. 
doi:10.1002/jbmr.4187

2. Guo Y, Wang Y, Chen F, Wang J, Wang D. Assessment of Risk Factors for Fractures in Patients with Type 2 Diabetes over 60 Years Old: A Cross-Sectional Study from Northeast China. J Diabetes Res. 2020;2020:1508258. Published 2020 Jan 27. doi:10.1155/2020/1508258

3. Chen F, Wang Y, Guo Y, et al. Specific higher levels of serum uric acid might have a protective effect on bone mineral density within a Chinese population over 60 years old: a cross-sectional study from northeast China. Clin Interv Aging. 2019;14:1065-1073. Published 2019 Jun 12. doi:10.2147/CIA.S186500

4. Beral V; Million Women Study Collaborators. Breast cancer and hormone-replacement therapy in the Million Women Study [published correction appears in Lancet. 2003 Oct 4;362(9390):1160]. Lancet. 2003;362(9382):419-427. doi:10.1016/s0140-6736(03)14065-2

5. Davison S, Davis SR. Hormone replacement therapy: current controversies. Clin Endocrinol (Oxf). 2003;58(3):249-261. doi:10.1046/j.1365-2265.2003.01774.x

6. Sieber P, Lardelli P, Kraenzlin CA, Kraenzlin ME, Meier C. Intravenous bisphosphonates for postmenopausal osteoporosis: safety profiles of zoledronic acid and ibandronate in clinical practice. Clin Drug Investig. 2013;33(2):117-122. doi:10.1007/s40261-012-0041-1

7. Wu H, Zhong Q, Wang J, et al. Beneficial Effects and Toxicity Studies of Xian-ling-gu-bao on Bone Metabolism in Ovariectomized Rats [published correction appears in Front Pharmacol. 2020 Nov 09;11:570876]. Front Pharmacol. 2017;8:273. Published 2017 May 22. doi:10.3389/fphar.2017.00273

8. Quarles LD, Yohay DA, Lever LW, Caton R, Wenstrup RJ. Distinct proliferative and differentiated stages of murine MC3T3-E1 cells in culture: an in vitro model of osteoblast development. J Bone Miner Res. 1992;7(6):683-692. doi:10.1002/jbmr.5650070613

9. Tevlek A, Odabas S, Çelik E, Aydin HM. Preparation of MC3T3-E1 cell sheets through short-term osteogenic medium application. Artif Cells Nanomed Biotechnol. 2018;46(sup2):1145-1153. doi:10.1080/21691401.2018.1481081

10. Yao B, Liu J, Zhang M, Leng X, Zhao D. Deciphering the potential pharmaceutical mechanism of Guzhi Zengsheng Zhitongwan on rat bone and kidney based on the "kidney governing bone" theory. J Orthop Surg Res. 2020;15(1):146. Published 2020 Apr 15. doi:10.1186/s13018-020-01677-8

11. Yao B, Lu B, Gao H, Zhang M, Leng X, Zhao D. Guzhi Zengsheng Zhitongwan, a Traditional Chinese Medicinal Formulation, Stimulates Chondrocyte Proliferation through Control of Multiple Genes Involved in Chondrocyte Proliferation and Differentiation. Evid Based Complement Alternat Med. 2018;2018:7265939. Published 2018 Sep 12. doi:10.1155/2018/7265939

12. Yao B, Lu B, Zhang M, Gao H, Leng X, Zhao D. The Chinese Medicinal Formulation Guzhi Zengsheng Zhitongwan Modulates Chondrocyte Structure, Dynamics, and Metabolism by Controlling Multiple Functional Proteins. Biomed Res Int. 2018;2018:9847286. Published 2018 Nov 22. doi:10.1155/2018/9847286 
13. Gregory CA, Gunn WG, Peister A, Prockop DJ. An Alizarin red-based assay of mineralization by adherent cells in culture: comparison with cetylpyridinium chloride extraction. Anal Biochem. 2004;329(1):77-84. doi:10.1016/j.ab.2004.02.002

14. Kim D, Langmead B, Salzberg SL. HISAT: a fast spliced aligner with low memory requirements. Nat Methods. 2015;12(4):357-360. doi:10.1038/nmeth.3317

15. Trapnell C, Williams BA, Pertea G, et al. Transcript assembly and quantification by RNA-Seq reveals unannotated transcripts and isoform switching during cell differentiation. Nat Biotechnol. 2010;28(5):511-515. doi:10.1038/nbt.1621

16. Benjamini $Y$, Hochberg Y. Controlling the false discovery rate - a practical and powerful approach to multiple testing. J Roy Stat Soc B Met. 1995;57:289-300.

17. Schmittgen TD, Livak KJ. Analyzing real-time PCR data by the comparative $C(T)$ method. Nat Protoc. 2008;3(6):1101-1108. doi:10.1038/nprot.2008.73

18. Hu L, Jonsson KB, Andersén $\mathrm{H}$, et al. Over-expression of Adamts 1 in mice alters bone mineral density. J Bone Miner Metab. 2012;30(3):304-311. doi:10.1007/s00774-011-0322-4

19. Shi Y, He G, Lee WC, McKenzie JA, Silva MJ, Long F. Gli1 identifies osteogenic progenitors for bone formation and fracture repair. Nat Commun. 2017;8(1):2043. Published 2017 Dec 11. doi:10.1038/s41467-017-02171-2

20. Su JL, Chiou J, Tang $\mathrm{CH}$, et al. CYR61 regulates BMP-2-dependent osteoblast differentiation through the \{alpha\} $\vee\{$ beta\}3 integrin/integrin-linked kinase/ERK pathway. J Biol Chem. 2010;285(41):3132531336. doi:10.1074/jbc.M109.087122

21. Liu M, Fan F, Shi P, et al. Lactoferrin promotes MC3T3-E1 osteoblast cells proliferation via MAPK signaling pathways. Int J Biol Macromol. 2018;107(Pt A):137-143.

doi:10.1016/j.ijbiomac.2017.08.151

22. Tanaka K, Hirai T, Kodama D, Kondo H, Hamamura K, Togari A. a1B -Adrenoceptor signaling regulates bone formation through the up-regulation of CCAAT/enhancer-binding protein $\delta$ expression in osteoblasts. Br J Pharmacol. 2016;173(6):1058-1069. doi:10.1111/bph.13418

23. Qu H, Li T, Jin H, Zhang S, He B. Silent Mating Type Information Regulation 2 Homolog (SIRT1) Influences Osteogenic Proliferation and Differentiation of MC3T3-E1 Cells via Regulation of miR-1323p. Med Sci Monit. 2019;25:2289-2295. Published 2019 Mar 29. doi:10.12659/MSM.912392

24. Zhou L, Wang SI, Moon YJ, et al. Overexpression of SIRT1 prevents hypoxia-induced apoptosis in osteoblast cells. Mol Med Rep. 2017;16(3):2969-2975. doi:10.3892/mmr.2017.6917

25. Qu B, Gong K, Yang H, et al. SIRT1 suppresses high glucose and palmitate-induced osteoclast differentiation via deacetylating p66Shc. Mol Cell Endocrinol. 2018;474:97-104. doi:10.1016/j.mce.2018.02.015

26. Chen L, Xiong Y, Yan C, et al. LncRNA KCNQ10T1 accelerates fracture healing via modulating miR701-3p/FGFR3 axis. FASEB J. 2020;34(4):5208-5222. doi:10.1096/fj.201901864RR

27. Wang K, Li S, Gao Y, et al. BCL3 regulates RANKL-induced osteoclastogenesis by interacting with TRAF6 in bone marrow-derived macrophages. Bone. 2018;114:257-267. 
doi:10.1016/j.bone.2018.06.015

28. Miyauchi Y, Ninomiya K, Miyamoto $\mathrm{H}$, et al. The Blimp1-Bcl6 axis is critical to regulate osteoclast differentiation and bone homeostasis. J Exp Med. 2010;207(4):751-762. doi:10.1084/jem.20091957

29. Chu Y, Zhao Z, Sant DW, et al. Tet2 Regulates Osteoclast Differentiation by Interacting with Runx1 and Maintaining Genomic 5-Hydroxymethylcytosine (5hmC). Genomics Proteomics Bioinformatics. 2018;16(3):172-186. doi:10.1016/j.gpb.2018.04.005

30. Simon D, Derer A, Andes FT, et al. Galectin-3 as a novel regulator of osteoblast-osteoclast interaction and bone homeostasis. Bone. 2017;105:35-41. doi:10.1016/j.bone.2017.08.013

31. Chen WT, Zhang F, Zhao XQ, Yu B, Wang BW. Galectin-3 and TRIM16 coregulate osteogenic differentiation of human bone marrow-derived mesenchymal stem cells at least partly via enhancing autophagy. Bone. 2020;131:115059. doi:10.1016/j.bone.2019.115059

32. Maeda A, Ono M, Holmbeck K, et al. WNT1-induced Secreted Protein-1 (WISP1), a Novel Regulator of Bone Turnover and Wnt Signaling. J Biol Chem. 2015;290(22):14004-14018. doi:10.1074/jbc.M114.628818

33. Yang Y, Su Y, Wang D, et al. Tanshinol attenuates the deleterious effects of oxidative stress on osteoblastic differentiation via Wnt/FoxO3a signaling. Oxid Med Cell Longev. 2013;2013:351895. doi:10.1155/2013/351895

34. Huang J, Hsu YH, Mo C, et al. METTL21C is a potential pleiotropic gene for osteoporosis and sarcopenia acting through the modulation of the NF-KB signaling pathway. $\mathrm{J}$ Bone Miner Res. 2014;29(7):1531-1540. doi:10.1002/jbmr.2200

35. Chang IC, Chiang TI, Lo C, et al. Anemone altaica Induces Apoptosis in Human Osteosarcoma Cells. Am J Chin Med. 2015;43(5):1031-1042. doi:10.1142/S0192415X15500597

36. Zhao L, Huang J, Guo R, Wang Y, Chen D, Xing L. Smurf1 inhibits mesenchymal stem cell proliferation and differentiation into osteoblasts through JunB degradation. J Bone Miner Res. 2010;25(6):1246-1256. doi:10.1002/jbmr.28

37. Zhang Q, Zuo H, Yu S, et al. RUNX2 co-operates with EGR1 to regulate osteogenic differentiation through Htra1 enhancers. J Cell Physiol. 2020;235(11):8601-8612. doi:10.1002/jcp.29704

38. Toan NK, Tai NC, Kim SA, Ahn SG. Soluble Klotho regulates bone differentiation by upregulating expression of the transcription factor EGR-1. FEBS Lett. 2020;594(2):290-300. doi:10.1002/18733468.13613

39. Chen Z, Li W, Wang H, et al. Klf10 regulates odontoblast differentiation and mineralization via promoting expression of dentin matrix protein 1 and dentin sialophosphoprotein genes. Cell Tissue Res. 2016;363(2):385-398. doi:10.1007/s00441-015-2260-2

40. Jang WG, Kim EJ, Kim DK, et al. BMP2 protein regulates osteocalcin expression via Runx2-mediated Atf6 gene transcription. J Biol Chem. 2012;287(2):905-915. doi:10.1074/jbc.M111.253187

41. Yang $X$, Yang J, Lei P, Wen T. LncRNA MALAT1 shuttled by bone marrow-derived mesenchymal stem cells-secreted exosomes alleviates osteoporosis through mediating microRNA-34c/SATB2 axis. Aging (Albany NY). 2019;11(20):8777-8791. doi:10.18632/aging.102264 
42. Al-Barghouthi BM, Mesner LD, Calabrese GM, et al. Systems genetics in diversity outbred mice inform BMD GWAS and identify determinants of bone strength. Nat Commun. 2021;12(1):3408. Published 2021 Jun 7. doi:10.1038/s41467-021-23649-0

43. Vlacic-Zischke J, Hamlet SM, Friis T, Tonetti MS, Ivanovski S. The influence of surface microroughness and hydrophilicity of titanium on the up-regulation of TGF $\beta / B M P$ signaling in osteoblasts. Biomaterials. 2011;32(3):665-671. doi:10.1016/j.biomaterials.2010.09.025

44. Huttunen MM, Pekkinen M, Ahlström ME, Lamberg-Allardt CJ. Long-term effects of tripeptide lle-ProPro on osteoblast differentiation in vitro. J Nutr Biochem. 2008;19(10):708-715. doi:10.1016/j.jnutbio.2007.09.006

45. Choi S, Kim KJ, Cheon S, et al. Biochemical activity of magnesium ions on human osteoblast migration. Biochem Biophys Res Commun. 2020;531(4):588-594. doi:10.1016/j.bbrc.2020.07.057

46. Xiao G, Cheng H, Cao H, et al. Critical role of filamin-binding LIM protein 1 (FBLP-1)/migfilin in regulation of bone remodeling. J Biol Chem. 2012;287(25):21450-21460. doi:10.1074/jbc.M111.331249

47. Besio R, Chow CW, Tonelli F, Marini JC, Forlino A. Bone biology: insights from osteogenesis imperfecta and related rare fragility syndromes. FEBS J. 2019;286(15):3033-3056. doi:10.1111/febs. 14963

48. Granholm S, Henning P, Lindholm C, Lerner UH. Osteoclast progenitor cells present in significant amounts in mouse calvarial osteoblast isolations and osteoclastogenesis increased by BMP-2. Bone. 2013;52(1):83-92. doi:10.1016/j.bone.2012.09.019

49. Honda T, Yamamoto $H$, Ishii A, Inui M. PDZRN3 negatively regulates BMP-2-induced osteoblast differentiation through inhibition of Wnt signaling. Mol Biol Cell. 2010;21(18):3269-3277. doi:10.1091/mbc.E10-02-0117

50. Komori T. Regulation of Proliferation, Differentiation and Functions of Osteoblasts by Runx2. Int J Mol Sci. 2019;20(7):1694. Published 2019 Apr 4. doi:10.3390/ijms20071694

51. Diegel CR, Hann S, Ayturk UM, et al. An osteocalcin-deficient mouse strain without endocrine abnormalities. PLoS Genet. 2020;16(5):e1008361. Published 2020 May 28. doi:10.1371/journal.pgen.1008361

52. Zhang X, Zhao G, Zhang Y, et al. Activation of JNK signaling in osteoblasts is inversely correlated with collagen synthesis in age-related osteoporosis. Biochem Biophys Res Commun. 2018;504(4):771-776. doi:10.1016/j.bbrc.2018.08.094

53. Diomede F, D'Aurora M, Gugliandolo A, et al. Biofunctionalized Scaffold in Bone Tissue Repair. Int J Mol Sci. 2018;19(4):1022. Published 2018 Mar 29. doi:10.3390/ijms19041022

54. Elefteriou F, Benson MD, Sowa H, et al. ATF4 mediation of NF1 functions in osteoblast reveals a nutritional basis for congenital skeletal dysplasiae. Cell Metab. 2006;4(6):441-451. doi:10.1016/j.cmet.2006.10.010

55. Lefebvre V, Bhattaram P. SOXC Genes and the Control of Skeletogenesis. Curr Osteoporos Rep. 2016;14(1):32-38. doi:10.1007/s11914-016-0296-1 
56. Komori T. Molecular Mechanism of Runx2-Dependent Bone Development. Mol Cells. 2020;43(2):168175. doi:10.14348/molcells.2019.0244

57. Tang Y, Lv L, Li W, et al. Protein deubiquitinase USP7 is required for osteogenic differentiation of human adipose-derived stem cells. Stem Cell Res Ther. 2017;8(1):186. Published 2017 Aug 14. doi:10.1186/s13287-017-0637-8

58. Al Mamun MA, Hosen MJ, Islam K, Khatun A, Alam MM, Al-Bari MA. Tridax procumbens flavonoids promote osteoblast differentiation and bone formation. Biol Res. 2015;48:65. Published 2015 Nov 18. doi:10.1186/s40659-015-0056-1

59. Alonso N, Larraz-Prieto B, Berg K, et al. Loss-of-Function Mutations in the ALPL Gene Presenting with Adult Onset Osteoporosis and Low Serum Concentrations of Total Alkaline Phosphatase. J Bone Miner Res. 2020;35(4):657-661. doi:10.1002/jbmr.3928

60. Ju D, Liu M, Zhao H, Wang J. Mechanisms of "kidney governing bones" theory in traditional Chinese medicine. Front Med. 2014;8(3):389-393. doi:10.1007/s11684-014-0362-y

61. Yao B, Liu J, Zhang M, Leng X, Zhao D. Deciphering the potential pharmaceutical mechanism of Guzhi Zengsheng Zhitongwan on rat bone and kidney based on the "kidney governing bone" theory. J Orthop Surg Res. 2020;15(1):146. Published 2020 Apr 15. doi:10.1186/s13018-020-01677-8

62. Song S, Gao Z, Lei X, et al. Total Flavonoids of Drynariae Rhizoma Prevent Bone Loss Induced by Hindlimb Unloading in Rats. Molecules. 2017;22(7):1033. Published 2017 Jun 22. doi:10.3390/molecules22071033

63. Zhao J, Ohba S, Shinkai M, Chung UI, Nagamune T. Icariin induces osteogenic differentiation in vitro in a BMP- and Runx2-dependent manner. Biochem Biophys Res Commun. 2008;369(2):444-448. doi:10.1016/j.bbrc.2008.02.054

64. Gong W, Zhang N, Cheng G, et al. Rehmannia glutinosa Libosch Extracts Prevent Bone Loss and Architectural Deterioration and Enhance Osteoblastic Bone Formation by Regulating the IGF1/PI3K/mTOR Pathway in Streptozotocin-Induced Diabetic Rats. Int J Mol Sci. 2019;20(16):3964. Published 2019 Aug 15. doi:10.3390/ijms20163964

65. Yan C, Zhang S, Wang C, Zhang Q. A fructooligosaccharide from Achyranthes bidentata inhibits osteoporosis by stimulating bone formation. Carbohydr Polym. 2019;210:110118. doi:10.1016/j.carbpol.2019.01.026

66. Pan Y, Niu Y, Li C, et al. Du-zhong (Eucommia ulmoides) prevents disuse-induced osteoporosis in hind limb suspension rats. Am J Chin Med. 2014;42(1):143-155. doi:10.1142/S0192415X14500104

67. Gao X, Liu Y, An Z, Ni J. Active Components and Pharmacological Effects of Cornus Officinalis: Literature Review. Front Pharmacol. 2021;12:633447. Published 2021 Apr 12. doi:10.3389/fphar.2021.633447

68. Wright LE, Frye JB, Timmermann BN, Funk JL. Protection of trabecular bone in ovariectomized rats by turmeric (Curcuma longa L.) is dependent on extract composition. J Agric Food Chem. 2010;58(17):9498-9504. doi:10.1021/jf101873f 
69. Liu H, Dong Y, Gao Y, et al. Hesperetin suppresses RANKL-induced osteoclastogenesis and ameliorates lipopolysaccharide-induced bone loss [published correction appears in J Cell Physiol. 2021 May;236(5):4091]. J Cell Physiol. 2019;234(7):11009-11022. doi:10.1002/jcp.27924

70. Wang Y, Dai J, Zhu Y, et al. Paeoniflorin regulates osteoclastogenesis and osteoblastogenesis via manipulating NF-KB signaling pathway both in vitro and in vivo. Oncotarget. 2017;9(7):7372-7388. Published 2017 Dec 27. doi:10.18632/oncotarget.23677

71. Guo W, Yang XG, Shi YL, Wang H. The effects and mechanism of paeoniflorin in promoting osteogenic differentiation of MC3T3-E1. J Orthop Surg Res. 2022;17(1):90. Published 2022 Feb 14. doi:10.1186/s13018-022-02965-1

72. Wang Y, Zhu Y, Lu S, Hu C, Zhong W, Chai Y. Beneficial effects of paeoniflorin on osteoporosis induced by high-carbohydrate, high-fat diet-associated hyperlipidemia in vivo. Biochem Biophys Res Commun. 2018;498(4):981-987. doi:10.1016/j.bbrc.2018.03.093

73. Zhi X, Wang $\mathrm{L}$, Chen $\mathrm{H}$, et al. I-tetrahydropalmatine suppresses osteoclastogenesis in vivo and in vitro via blocking RANK-TRAF6 interactions and inhibiting NF-KB and MAPK pathways. J Cell Mol Med. 2020;24(1):785-798. doi:10.1111/jcmm.14790

74. Yang RS, Lu YH, Chiang W, Liu SH. Osteoporosis Prevention by Adlay ( Yì Yí: The Seeds of Coix Lachryma-Jobi L. var. ma-yuen Stapf) in a Mouse Model. J Tradit Complement Med. 2013;3(2):134138. doi:10.4103/2225-4110.110408

75. Yang RS, Chiang W, Lu YH, Liu SH. Evaluation of osteoporosis prevention by adlay using a tissue culture model. Asia Pac J Clin Nutr. 2008;17 Suppl 1:143-146.

\section{Tables}

Table 1 Statistical sequencing results of Blank and GJD.

\begin{tabular}{lll}
\hline Statistics & Blank & GJD \\
\hline OD260/280 & 2.0 & 2.0 \\
OD260/ 230 & 2.0 & 2.0 \\
RIN* & 10.0 & 10.0 \\
Clean reads & $44,599,448$ & $47,323,148$ \\
Q30 percentage & 95.51 & 95.43 \\
GC percentage & 52.16 & 51.36 \\
Total mapped reads & $41,360,834$ & $44,185,514$ \\
Total transcripts & 13,070 & 13,383 \\
Known transcripts & 12,977 & 13,282 \\
\hline
\end{tabular}

Table 2 Statistical analysis of DEGs (Blank versus GJD).

\begin{tabular}{ll}
\hline Statistics & Number \\
\hline Differentially expressed mRNAs & 362 \\
Upregulated mRNAs & 346 \\
Downregulated mRNAs & 16 \\
\hline
\end{tabular}


Table 3 The expression levels of multiple genes that positively regulate the proliferation of MC3T3-E1 cells or osteoblasts (Blank versus GJD).

\begin{tabular}{|c|c|c|c|c|c|}
\hline Gene name & $\begin{array}{l}\text { Blank } \\
\text { (FPKM) }\end{array}$ & $\begin{array}{l}\text { GJD } \\
\text { (FPKM) }\end{array}$ & $\begin{array}{lr}\text { Log2 } & \text { fold } \\
\text { change } & \text { (GJD } \\
\text { /Blank) } & \end{array}$ & P value & $\overline{\text { FDR }}$ \\
\hline A disintegrin & 33 & 93.91 & 1.508812767 & $2.64581999999996 \mathrm{e}^{-}$ & $6.13 \mathrm{E}-307$ \\
\hline $\begin{array}{l}\text { metalloproteinase with } \\
\text { thrombospondin motifs } 10 \\
\text { (Adamts1) }\end{array}$ & & & & (2) & \\
\hline $\begin{array}{l}\text { Melanoma cell adhesion } \\
\text { molecule (Mcam) }\end{array}$ & 26.55 & 67.15 & 1.338675539 & 8.00E-108 & 2.78E-105 \\
\hline Protein CYR61 (Cyr61) & 16.92 & 44.19 & 1.384990363 & $6.29 \mathrm{E}-52$ & $8.01 \mathrm{E}-50$ \\
\hline Proto-oncogene c-Fos (Fos) & 2.73 & 11.85 & 2.117914203 & $4.31 \mathrm{E}-27$ & $1.91 \mathrm{E}-25$ \\
\hline $\begin{array}{l}\text { CCAAT/enhancer-binding } \\
\text { protein delta (Cebpd) }\end{array}$ & 1.39 & 8.66 & 2.639282142 & $1.00 \mathrm{E}-27$ & $4.57 \mathrm{E}-26$ \\
\hline $\begin{array}{l}\text { Fos-related antigen } 2 \\
\text { (Fosl2) }\end{array}$ & 3.77 & 7.74 & 1.037769043 & 7.76E-19 & $2.01 \mathrm{E}-17$ \\
\hline $\begin{array}{l}\text { NAD-dependent } \\
\text { deacetylase } \\
\text { (Sirt1) }\end{array}$ & 1.5 & 3.33 & 1.150559677 & 4.55E-07 & $3.28 \mathrm{E}-06$ \\
\hline $\begin{array}{l}\text { Nipped-B-like } \quad \text { protein } \\
\text { (Nipbl) }\end{array}$ & 1.12 & 2.64 & 1.237039197 & 7.06E-16 & $1.44 \mathrm{E}-14$ \\
\hline Semaphorin-3C (Sema3c) & 0.65 & 1.53 & 1.23502003 & 3.87E-05 & 0.000199284 \\
\hline $\begin{array}{l}\text { KCNQ1 } \\
\text { transcript } 1 \text { (Kcnq1 ot1) }\end{array}$ & 0.01 & 0.07 & 2.807354922 & 5.48E-10 & 6.00E-09 \\
\hline
\end{tabular}

Table 4 Positive regulation of differentially expressed genes that inhibit osteoblast apoptosis (Blank versus GJD).

\begin{tabular}{|c|c|c|c|c|c|}
\hline Gene name & $\begin{array}{l}\text { Blank } \\
\text { (FPKM) }\end{array}$ & $\begin{array}{l}\text { GJD } \\
\text { (FPKM) }\end{array}$ & $\begin{array}{l}\text { log2 fold change } \\
\text { (GJD /Blank) }\end{array}$ & $\begin{array}{l}\mathrm{P} \\
\text { value }\end{array}$ & FDR \\
\hline \multirow{4}{*}{$\begin{array}{l}\text { Growth arrest and DNA-damage-inducible } \\
45 \text { alpha (Gadd45a) } \\
\text { Baculoviral IAP repeat-containing protein } 3 \\
\text { (Birc3) } \\
\text { NAD-dependent protein deacetylase sirtuin- } \\
1 \text { (Sirt1) } \\
\text { Heat shock protein 1B (Hspa1b) }\end{array}$} & 8.97 & 65.51 & 2.868535258 & \multirow{4}{*}{$\begin{array}{l}1.74 \mathrm{E}- \\
110 \\
5.73 \mathrm{E}- \\
07 \\
4.55 \mathrm{E}- \\
07 \\
2.11 \mathrm{E}- \\
10\end{array}$} & \multirow{4}{*}{$\begin{array}{l}6.53 \mathrm{E}- \\
108 \\
4.04 \mathrm{E}- \\
06 \\
3.28 \mathrm{E}- \\
06 \\
2.42 \mathrm{E}- \\
09\end{array}$} \\
\hline & 0.31 & 1.64 & 2.403355694 & & \\
\hline & 1.5 & 3.33 & 1.150559677 & & \\
\hline & 6.05 & 2.47 & -1.292424101 & & \\
\hline
\end{tabular}

Table 5 Differential gene expression that inhibits the growth or differentiation of osteoclasts (Blank versus GJD). 


\begin{tabular}{|c|c|c|c|c|c|}
\hline Gene name & $\begin{array}{l}\text { Blank } \\
\text { (FPKM) }\end{array}$ & $\begin{array}{l}\text { GJD } \\
\text { (FPKM) }\end{array}$ & $\begin{array}{l}\text { Log2 fold } \\
\text { (GJD /Blank) }\end{array}$ & $\begin{array}{l}\mathrm{P} \\
\text { value }\end{array}$ & FDR \\
\hline \multirow{2}{*}{$\begin{array}{l}\text { B-cell lymphoma } 6 \text { protein homolog } \\
\text { (Bcl6) } \\
\text { NF-kappa-B inhibitor zeta (Nfkbiz) }\end{array}$} & 0.95 & 3.95 & 2.055853235 & \multirow{10}{*}{$\begin{array}{l}5.06 \mathrm{E}- \\
15 \\
2.53 \mathrm{E}- \\
09 \\
4.55 \mathrm{E}- \\
07 \\
8.02 \mathrm{E}- \\
08 \\
7.15 \mathrm{E}- \\
08 \\
9.25 \mathrm{E}- \\
98 \\
9.78 \mathrm{E}- \\
24 \\
8.37 \mathrm{E}- \\
10 \\
1.22 \mathrm{E}- \\
06 \\
5.48 \mathrm{E}- \\
10\end{array}$} & \multirow{10}{*}{$\begin{array}{l}9.54 \mathrm{E}- \\
14 \\
2.54 \mathrm{E}- \\
08 \\
3.28 \mathrm{E}- \\
06 \\
6.60 \mathrm{E}- \\
07 \\
5.94 \mathrm{E}- \\
07 \\
9.25 \mathrm{E}- \\
98 \\
3.58 \mathrm{E}- \\
22 \\
2.35 \mathrm{E}- \\
10 \\
8.14 \mathrm{E}- \\
06 \\
6.00 \mathrm{E}- \\
09\end{array}$} \\
\hline & 1.2 & 3.38 & 1.493988841 & & \\
\hline NAD-dependent protein deacetylase & 1.5 & 3.33 & 1.150559677 & & \\
\hline Cardiotrophin-like cytokine factor 1 & 0.37 & 2.52 & 2.767826558 & & \\
\hline $\begin{array}{l}\text { (Clct1) } \\
\text { B-cell lymphoma } 3 \text { protein homolog }\end{array}$ & 0.25 & 2.26 & 3.176322773 & & \\
\hline $\begin{array}{l}\text { (Bcl3) } \\
\text { Lectin, galactose binding, soluble } 3\end{array}$ & 107 & 217 & 1.01 & & \\
\hline WNT1-inducible-signaling & 4.06 & 9.31 & 1.19730144 & & \\
\hline Dual specificity protein phosphatase 1 & 3.55 & 8.6 & 1.276517635 & & \\
\hline $\begin{array}{l}\text { (Dusp1) } \\
\text { Filamin-binding LIM protein } 1 \text { (Fblim1) }\end{array}$ & 0.75 & 2.3 & 1.61 & & \\
\hline $\begin{array}{l}\text { KCNQ1 overlapping transcript } \\
\text { (Kcng1ot1) }\end{array}$ & 0.01 & 0.07 & 2.807354922 & & \\
\hline
\end{tabular}

Table 6 The expression levels of several genes that promote differentiation of MC3T3-E1 cells and osteoblasts (Blank versus GJD) 


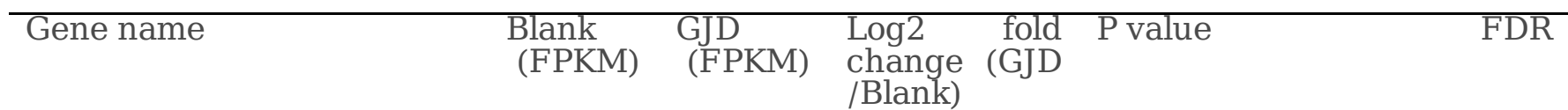

\begin{tabular}{lrlllll}
\hline Lectin, galactose & binding, & 107.48 & 217 & 1.013626816 & $9.25 \mathrm{E}-98$ & $9.25 \mathrm{E}-98$ \\
soluble 3 (Lgals3) & and & 33 & 93.91 & 1.508812767 & $2.64581999999996 \mathrm{e}-$ & $6.13 \mathrm{E}-307$ \\
$\mathrm{~A}$ disintegrin & $\begin{array}{r}\text { and } \\
\text { metalloproteinase }\end{array}$ & & & & 310 &
\end{tabular}

thrombospondin motifs 10

(Adamts1)

\begin{tabular}{|c|c|c|c|c|c|}
\hline Transcription factor jun-B & 27.21 & 61.73 & 1.181834835 & $5.78 \mathrm{E}-51$ & $6.98 \mathrm{E}-49$ \\
\hline (Junb) growth response & 4.07 & 12.77 & 1.649657825 & $5.01 \mathrm{E}-31$ & $2.72 \mathrm{E}-29$ \\
\hline $\begin{array}{l}\text { protein 1 (Egr1) } \\
\text { Krueppel-like factor } 10 \\
\text { (Klf10) }\end{array}$ & 4.53 & 9.49 & 1.066897037 & $1.03 \mathrm{E}-12$ & $1.50 \mathrm{E}-11$ \\
\hline $\begin{array}{l}\text { Activating transcription } \\
\text { factor } 6 \text { beta (Atf6) }\end{array}$ & 3.79 & 9.45 & 1.318116481 & $7.73 E-41$ & $6.80 \mathrm{E}-39$ \\
\hline WNT1-inducible-signaling & 4.06 & 9.31 & 1.19730144 & $9.78 \mathrm{E}-24$ & $3.58 \mathrm{E}-22$ \\
\hline $\begin{array}{l}\text { patnway proteln } \\
\text { metastasis associated lung } \\
\text { adenocarcinoma transcript } \\
1 \text { (non-coding RNA) } \\
\text { (Malat1) }\end{array}$ & 2.86 & 9.08 & 1.666677151 & 1.93E-51 & $2.35 \mathrm{E}-49$ \\
\hline Protein BTG2 (Btg2) & 3.59 & 7.53 & 1.068666021 & 1.82E-10 & 2.09E-09 \\
\hline $\begin{array}{l}\text { NAD-dependent protein } \\
\text { deacetylase } \\
\text { (Sirt1) }\end{array}$ & 1.5 & 3.33 & 1.150559677 & $4.55 \mathrm{E}-07$ & $3.28 \mathrm{E}-06$ \\
\hline $\begin{array}{l}\text { SERTA domain-containing } \\
\text { protein } 4 \text { (Sertad } 4)\end{array}$ & 0.95 & 3.09 & 1.70160742 & 3.29E-09 & $3.26 \mathrm{E}-08$ \\
\hline $\begin{array}{l}\text { Zinc finger FYVE domain- } \\
\text { containing protein } 16\end{array}$ & 1.35 & 2.97 & 1.137503524 & $1.45 \mathrm{E}-08$ & $1.31 \mathrm{E}-07$ \\
\hline $\begin{array}{l}\text { Tet methylcytosine } \\
\text { dioxyqenase } 2 \text { (Tet2) }\end{array}$ & 1.29 & 2.91 & 1.173648087 & $3.91 \mathrm{E}-14$ & $6.70 \mathrm{E}-13$ \\
\hline $\begin{array}{l}\text { cAMP responsive element } \\
\text { binding protein } 5 \text { (Creb5) }\end{array}$ & 0.54 & 2.56 & 2.245112498 & $9.41 \mathrm{E}-10$ & $9.91 \mathrm{E}-09$ \\
\hline $\begin{array}{l}\text { Zinc finger protein } \\
\text { SNAI2(Snai2) }\end{array}$ & 0.81 & 2.38 & 1.55496776 & 0.000580148 & 0.000580148 \\
\hline $\begin{array}{ll}\text { Filamin-binding } & \text { LIM } \\
\text { protein 1 (Fblim } 1) & \end{array}$ & 0.75 & 2.3 & 1.61667136 & 1.22E-06 & 8.14E-06 \\
\hline $\begin{array}{l}\text { Protein FAM46A isoform } 1 \\
\text { (Fam46a) }\end{array}$ & 0.27 & 1.04 & 1.945552216 & $7.44 \mathrm{E}-07$ & 5.16E-06 \\
\hline $\begin{array}{l}\text { Calcitonin } \\
\text { peptide type } 1 \text { (Calcrl) }\end{array}$ & 0.07 & 0.52 & 2.893084796 & 4.64E-05 & 0.000235506 \\
\hline $\begin{array}{l}\text { KCNQ1 } \\
\text { transcript } 1 \text { (Kcnq1 } 1 \text { ot1) }\end{array}$ & 0.01 & 0.07 & 2.807354922 & $5.48 \mathrm{E}-10$ & 6.00E-09 \\
\hline $\begin{array}{l}\text { PDZ domain containing } \\
\text { RING finger } 3 \text { (Pdzrn3) }\end{array}$ & 1.16 & 0.3 & -1.9510904 & 5.76E-06 & $3.46 \mathrm{E}-05$ \\
\hline
\end{tabular}

Table 7 The expression level of osteoblast markers (Blank versus GJD). 


\begin{tabular}{|c|c|c|c|c|c|}
\hline Gene name & $\begin{array}{l}\text { Blank } \\
\text { (FPKM) }\end{array}$ & $\begin{array}{l}\text { GJD } \\
\text { (FPKM) }\end{array}$ & $\begin{array}{l}\text { Log2 fold change } \\
\text { (GJD /Blank) }\end{array}$ & P value & FDR \\
\hline Activating transcription factor & 172.7 & 320.77 & 0.893271137 & $9.24 \mathrm{E}-154$ & $7.13 \mathrm{E}-151$ \\
\hline $\begin{array}{l}4 \text { (At14) } \\
\text { Fibronectin } 1 \text { (Fn1) } \\
\text { Ubiquitin specific peptidase } 7\end{array}$ & $\begin{array}{l}27.4 \\
27.12\end{array}$ & $\begin{array}{l}46.91 \\
30.85\end{array}$ & $\begin{array}{l}0.775719608 \\
0.185913311\end{array}$ & $\begin{array}{l}1.08 \mathrm{E}-89 \\
0.000421942\end{array}$ & $\begin{array}{l}2.83 \mathrm{E}-87 \\
0.00174401\end{array}$ \\
\hline $\begin{array}{l}\text { (Usp7) } \\
\text { Transcription factor } \text { SOX-4 }\end{array}$ & 13.96 & 17.02 & 0.285932095 & 0.00395968 & 0.012846304 \\
\hline $\begin{array}{l}\text { (Sox4) } \\
\text { Collagen alpha-1(XVI) chain }\end{array}$ & 9.5 & 12.82 & 0.432396843 & $6.57 \mathrm{E}-07$ & 4.59E-06 \\
\hline Osteopontin isoform 1 (Spp1) & $\begin{array}{l}4.09 \\
7.81\end{array}$ & $\begin{array}{l}8.49 \\
7.85\end{array}$ & $\begin{array}{l}1.053663711 \\
0.007370106\end{array}$ & $\begin{array}{l}1.35 \mathrm{E}-05 \\
0.759444\end{array}$ & $\begin{array}{l}\text { 7.67E-05 } \\
0.831575317\end{array}$ \\
\hline Runt related transcription & 0.79 & 1.5 & 0.925037942 & 0.000763496 & 0.002966849 \\
\hline $\begin{array}{l}\text { tactor } 2 \text { (Runx2) } \\
\text { Bone gamma-carboxyglutamate }\end{array}$ & 0.01 & 0.31 & 4.95419631 & 0.524294 & 0.623728275 \\
\hline 1 & 0.24 & 0.32 & 0.415037499 & 0.294958 & 0.446502837 \\
\hline $\begin{array}{l}\text { Alkaline phosphatase, tissue- } \\
\text { nonspecific isozyme (Alpl) }\end{array}$ & 0.01 & 0.13 & 3.700439718 & 0.137442 & 0.254613184 \\
\hline
\end{tabular}

Table 8 Primer sequences used in qRT-PCR validation.

\begin{tabular}{|c|c|c|}
\hline Gene name & Primer & Sequence \\
\hline $\begin{array}{l}\text { Adamts1 } \\
\text { Mcan } \\
\text { Cebpd } \\
\text { Gadd45a } \\
\text { Bcl3 } \\
\text { Nfkbiz } \\
\text { JunB } \\
\text { Klf10 } \\
\text { Hspa1b } \\
\text { Gapdh }\end{array}$ & $\begin{array}{l}\text { Forward primer } \\
\text { Reverse primer } \\
\text { Forward primer } \\
\text { Reverse primer } \\
\text { Forward primer } \\
\text { Reverse primer } \\
\text { Forward primer } \\
\text { Reverse primer } \\
\text { Forward primer } \\
\text { Reverse primer } \\
\text { Forward primer } \\
\text { Reverse primer } \\
\text { Forward primer } \\
\text { Reverse primer } \\
\text { Forward primer } \\
\text { Reverse primer } \\
\text { Forward primer } \\
\text { Reverse primer } \\
\text { Forward primer } \\
\text { Reverse primer }\end{array}$ & $\begin{array}{l}\text { TACTGACTTCCTGGGATAGTGGG } \\
\text { TGGCTCAAACTGTAGCTTGTG } \\
\text { CCCAACTGGTGGCGTCTT } \\
\text { GGAAAATCAGTATCTGCCTCTCC } \\
\text { CGACTTCAGCGCCTACATTGA } \\
\text { CTAGCGACAGACCCCACAC } \\
\text { CCGAAAGGATGACACGGTG } \\
\text { TTATCGGGGTCTACGTTGAGC } \\
\text { CCGGAGGCCCTTTACTACCA } \\
\text { GGAGTAGGGGTGAGTAGGCAG } \\
\text { GCTCCGACTCCTCCGATTC } \\
\text { GAGTTCTTCACGCGAACACC } \\
\text { TCACGACGACTCTTACGCAG } \\
\text { CCTTGAGACCCCGATAGGGA } \\
\text { ATGCTCAACTTCGGCGCTT } \\
\text { CGCTTCCACCGCTTCAAAG } \\
\text { GAGATCGACTCTCTGTTCGAGG } \\
\text { GCCCGTTGAAGAAGTCCTG } \\
\text { AGGTCGGTGTGAACGGATTG } \\
\text { TGTAGACCATGTAGTTGAGGTCA }\end{array}$ \\
\hline
\end{tabular}

\section{Figures}


A

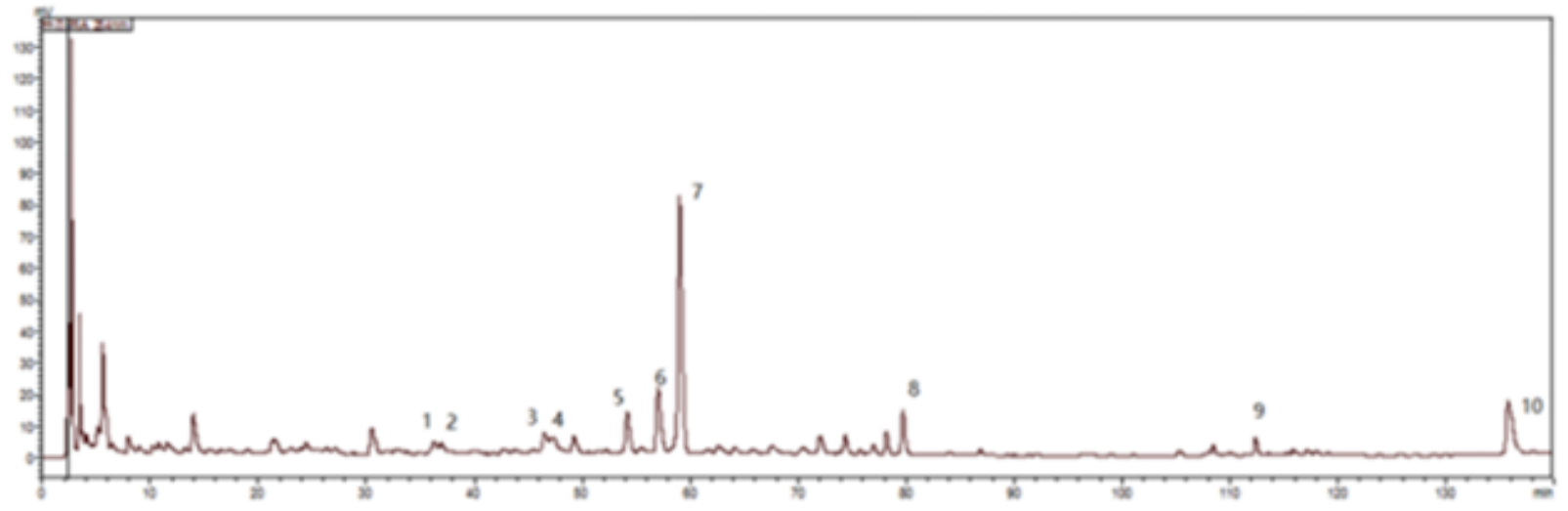

\section{B}
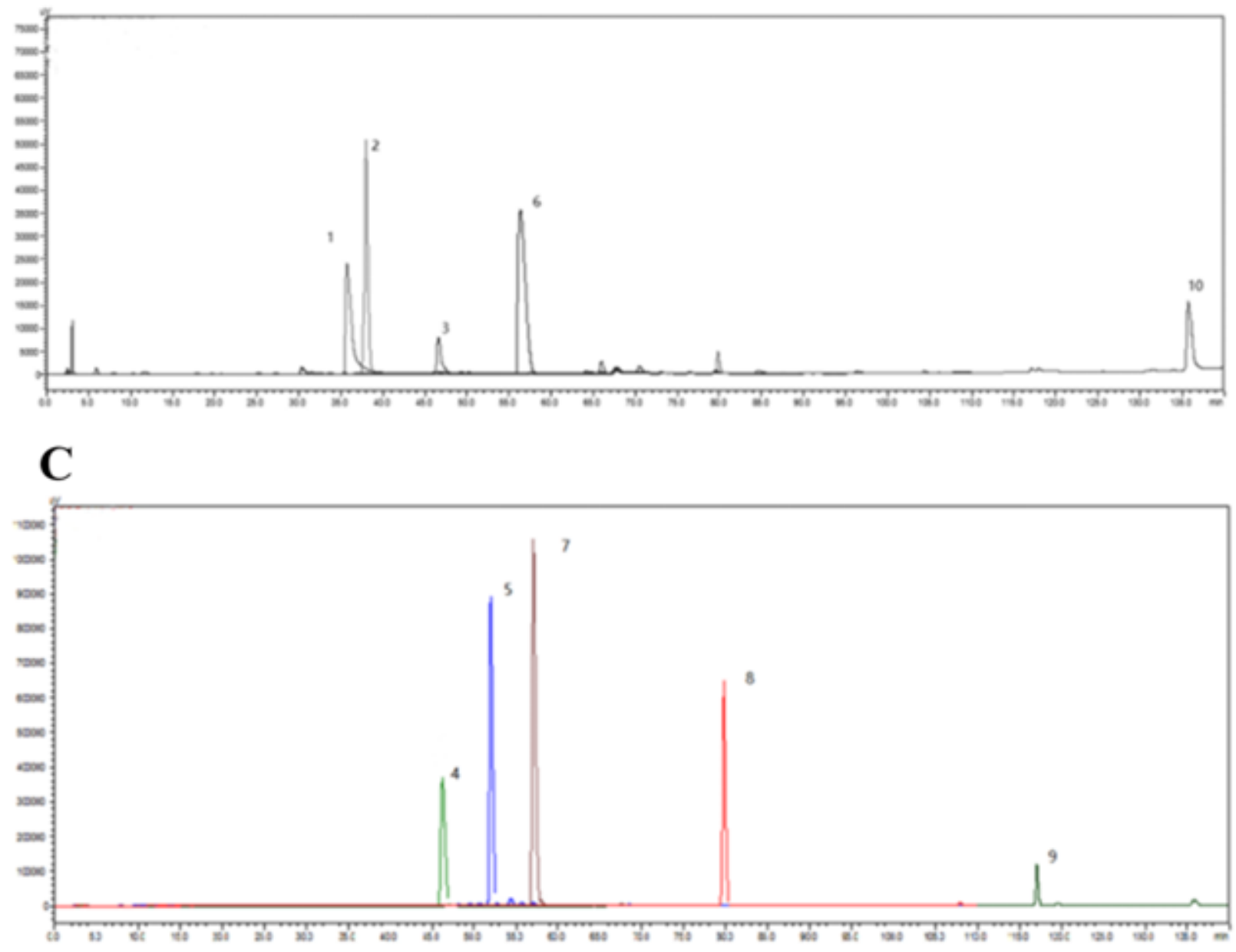

\section{Figure 1}

A: HPLC of GJD extract, The ordinate represents the signal response units (mAU), while the abscissa represents the retention time (min). B-C: HPLC of standard chemicals. Ten major components were identified: 1: Paeoniflorin, 2: Pinoresinol diglucoside, 3:Loganin, 4: Liquiritin, 5: Acteoside, 6:Tetrahydropalmatine, 7:Naringin, 8:Icariin, 9:Ammonium glycyrrhetate, 10:Catalpol. 


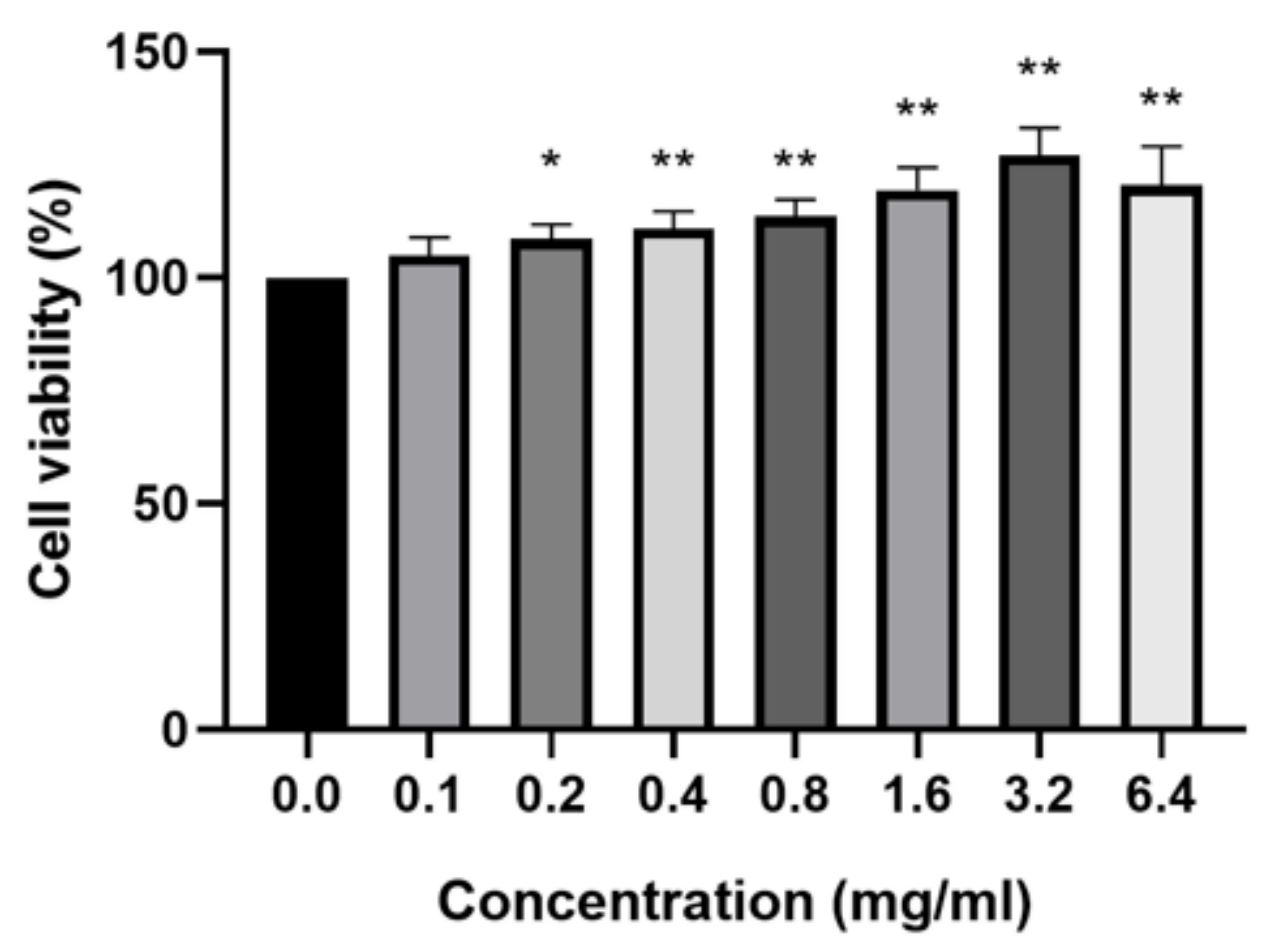

Figure 2

Effects of GJD on MC3T3-E1 cell proliferation. Cell viability was detected by CCK-8 assay after the treatment with GJD at progressively increasing concentration-dependent of $0,0.1,0.2,0.4,0.8,1.6,3.2$, and $6.4 \mathrm{mg} / \mathrm{mL}$ was estimated by normalising to cell viability of the untreated group $(0 \mathrm{mg} / \mathrm{mL})$. Data are presented as the mean with standard deviation for technical triplicates in an experiment representative of several independent ones. $*: p<0.01, * *: p<0.001$ represent the differences of cell viabilities under GJD treatment (Ordinary one-way ANOVA). 

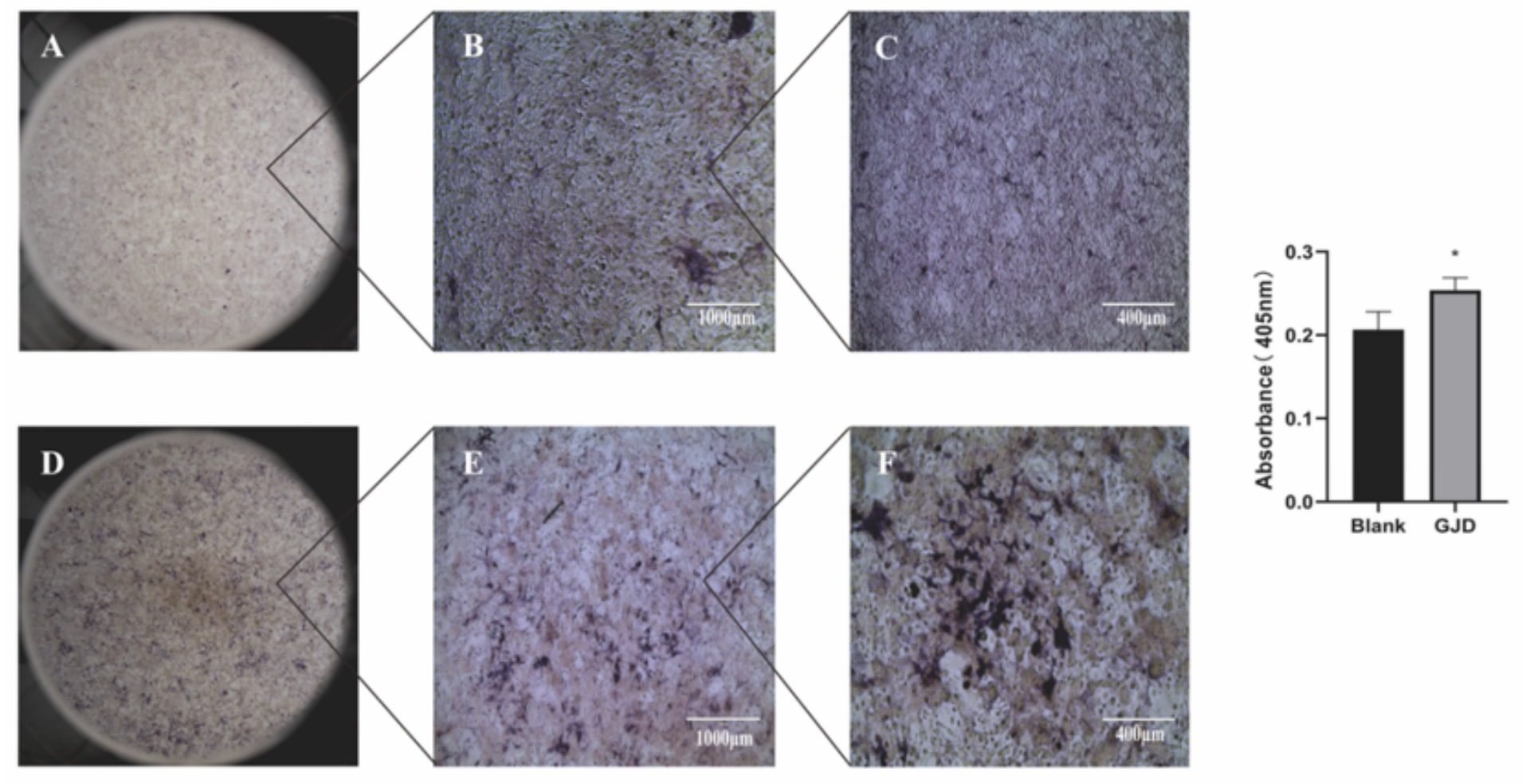

Figure 3

Effect of GJD on proliferation and differentiation of MC3T3-E1 cells. Alkaline phosphatase was used to visualise the deposition of extracellular matrix in MC3T3-E1 cells, and the amount of alkaline phosphatase staining was quantified by detecting absorbance at $405 \mathrm{~nm}$. A-C are Blanks and D-F are MC3T3-E1 cells after GJD treatment. ( $*$ p < 0.05) 


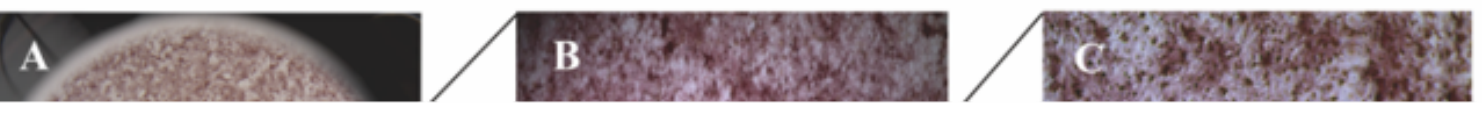

\section{Figure 4}

Effect of GJD on proliferation and differentiation of MC3T3-E1 cells. (a) Deposition of extracellular matrix in MC3T3-E1 cells as observed by alizarin red S staining. (b) Quantification of the amount of alizarin red staining by detection of absorbance at $405 \mathrm{~nm}$. A-C are untreated blanks, and D-F are GJD-treated MC3T3-E1 cells. *: $p<0.05$ 
A

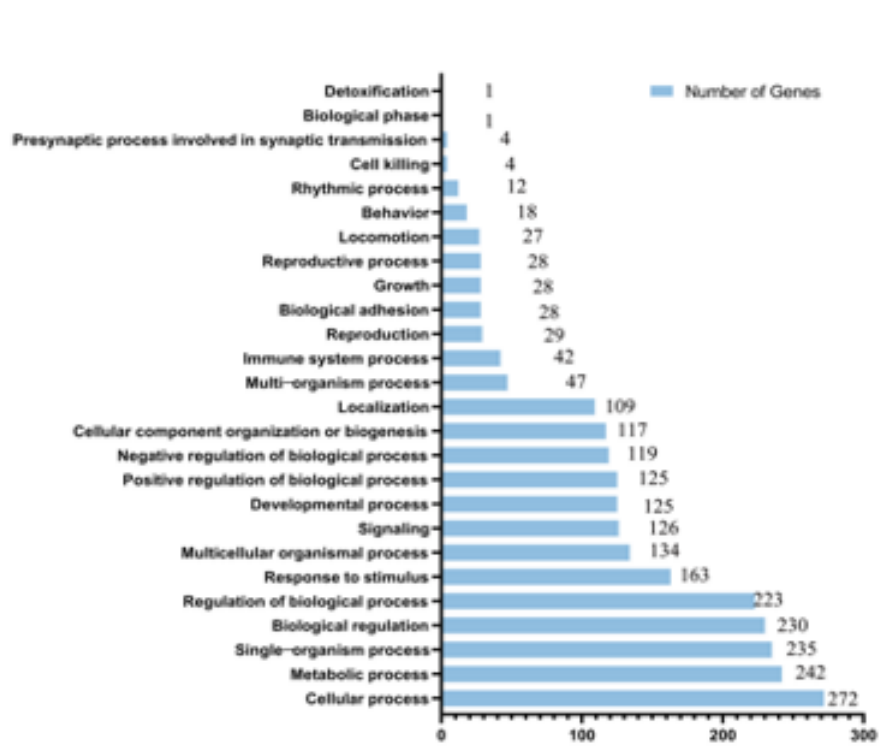

C Molecular Function

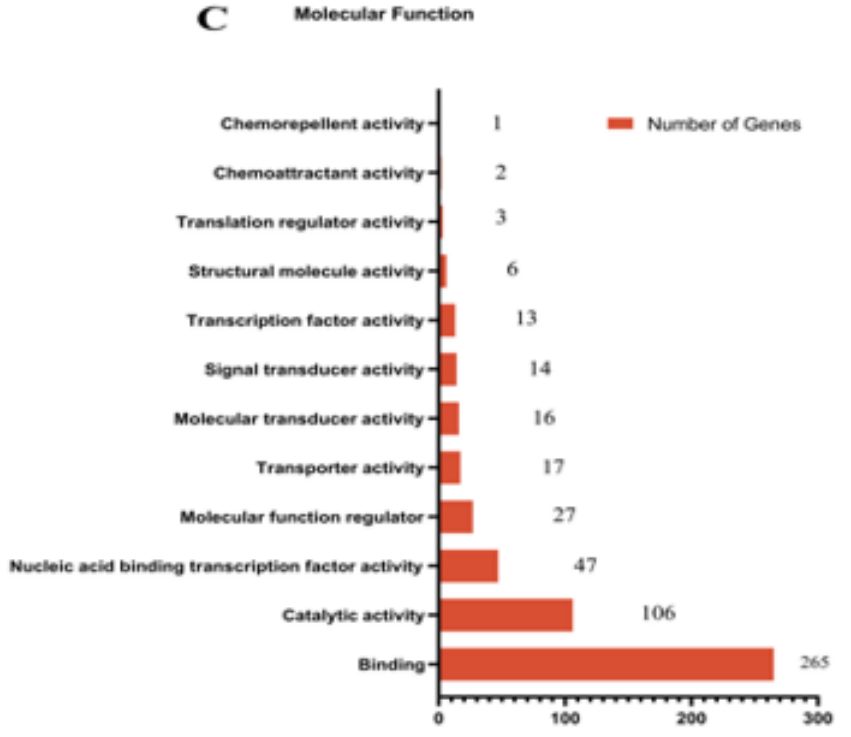

\section{Figure 5}

Histograms of GO enrichment analysis of DEGs are shown. A-C results are divided into three categories: biological processes, cellular components, and molecular functions. The x-axis indicates the number of DEGs corresponding to the GO term and the y-axis indicates the name of the GO term. 

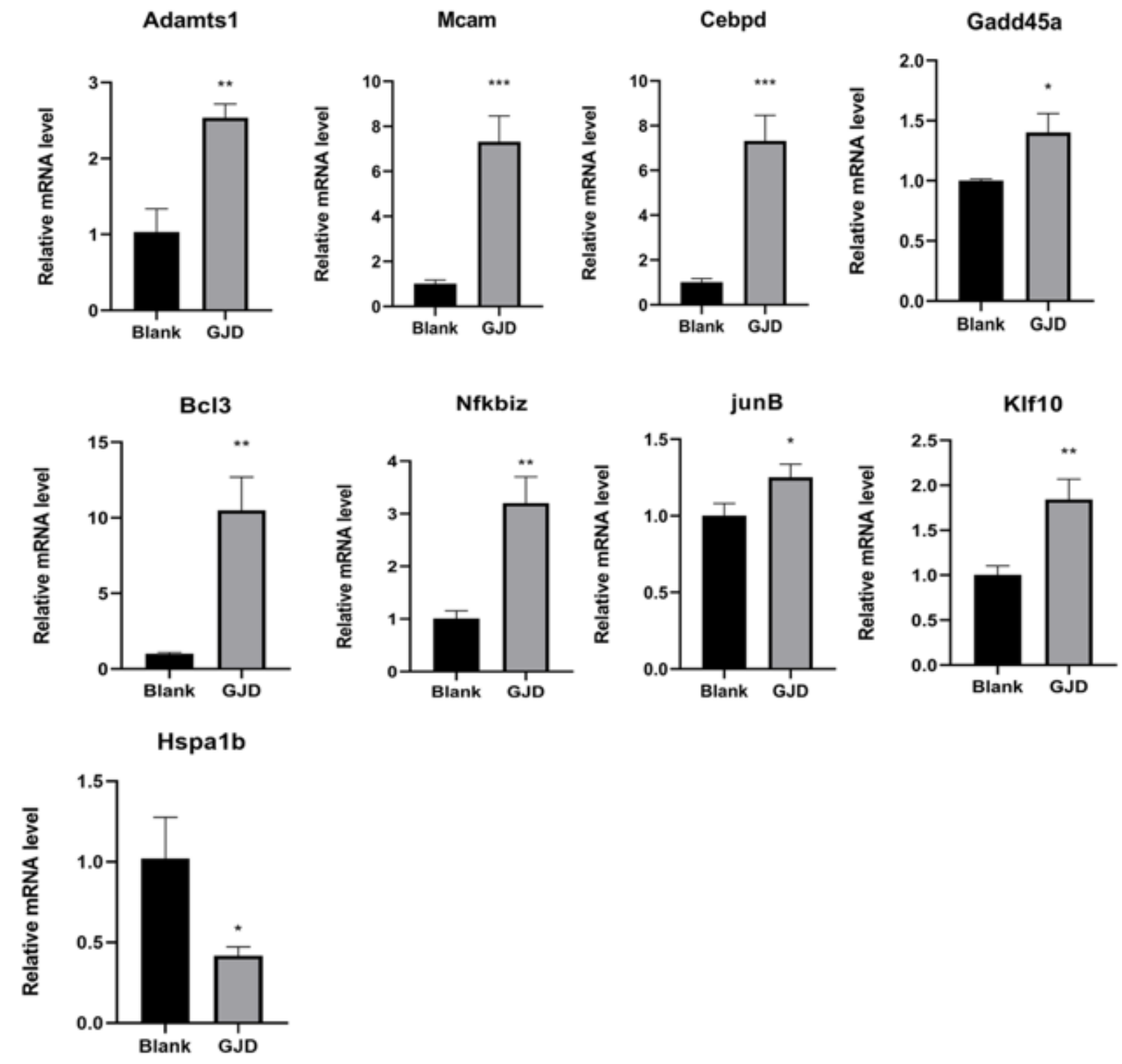

Figure 6

Validation of RNA-seq data by qRT-PCR assay. The relative mRNA levels of the selected DEGs were quantified by qRT-PCR. In experiments representing several independent experiments, data are expressed as mean and standard deviation of the technique in triplicate. $*: p<0.05, * *: p<0.01$ and $* \star \star: p<0.001$ represent differences in relative mRNA levels under GJD treatment (Student's t-test). 